Published in INDUSTRIAL AND LABOR RELATIONS REVIEW, 2002

\title{
Logics of Action, Globalization, and Changing Employment Relations in China, India, Malaysia and Philippines
}

\author{
Stephen Frenkel \\ Professor of Management \\ University of New South Wales \\ and \\ Sarosh Kuruvilla \\ Professor of Comparative Industrial Relations, Collective Bargaining and Asian Studies \\ Cornell University
}

Address Correspondence to:

Sarosh Kuruvilla

156 Ives Hall

Cornell University

Ithaca, NY 14853-3901

Acknowledgements: We would like to thank the ILO-Japan Program for funding the research on which this paper is based, and in particular, David Macdonald and Duncan Campbell, of the ILO. We also acknowledge the contributions of the various researchers involved in the project. These include Maragtas Amante, Mark Anner, Stephen Chiu, Christopher Erickson, Wesley Hiers, Rene Ofreneo, Ina Ortiz, David Peetz and Trish Todd. We thank Harry Katz, Christopher Erickson and three anonymous reviewers for helpful comments. 


\section{$\underline{\text { Abstract }}$}

A logic of action framework is developed in order to conceptualize and understand the impact of globalization on employment relations, as well as to predict the future trajectory of employment relations. The argument is that the interplay between three different logics of action, i.e., the logic of competition, the logic of industrial peace, and the logic of employmentincome protection determines the employment relations pattern in any given nation. The strengths of the logics themselves are determined by five often related factors, i.e., economic development strategy, the intensity of globalization, union strength, labor market features and government responsiveness to workers. Drawing on extensive field research on national policies and workplace practices in India, China, the Philippines and Malaysia, we show support for our framework. We find that ER patterns are reflect different combinations of logic strengths, that globalization's impact on employment relations is not only complex, but contingent, and we suggest that long term convergence in employment relations is unlikely given variations in the combinations of logic strengths in different countries, and changes in logic strengths over time. 
The argument in this article contributes to two continuing debates in contemporary industrial relations, namely the impact of globalization on employment relations (ER), and whether or not national ER systems are converging or diverging. ${ }^{1}$ With regard to the first debate, supporters of globalization argue that free trade and increased foreign direct investment will increase employment and earnings in advanced and developing countries. Critics maintain that in practice globalization has a deleterious effect on wages, employment, and working conditions on most, though not all, developing country workers. This results from competition by multinationals and the selective opening of markets to international trade in favor of the advanced countries (Sen 2001; Singh and Zammit 2000). Leisink (1999) observes that this debate exists in part, due to limited empirical evidence, worldwide, on the impact of globalization on ER.

Controversy about the impact of globalization on ER has rejuvenated the older debate regarding the longer run trajectory of ER systems. Although some well-known views about convergence (Kerr, Dunlop, Harbison and Myers 1960, 1973; Kerr, 1983; Dore 1974, 1989, Lincoln and Kalleberg, 1990) have not been supported by experience (there has been persistent divergence in ER systems in industrialized nations), some recent arguments have emphasized convergence at the workplace. This arises from increased competition -- e.g., convergence on a dual model with the "high road," functionally flexible workplaces characterized by high pay and team based work producing complex goods and services mainly in the advanced countries and the "low road" numerically flexible, non-union, Taylorist work practice model producing simple

\footnotetext{
${ }^{1}$ The term globalization refers to growing international economic integration, based significantly on the activities of multinational corporations. Although not a new phenomenon, the 1980s and 1990s have seen a surge of international trade and investment, mostly centered around advanced industrial economies. However, recently, many developing economies have become more closely integrated into the global economy, although for several, the process is only at an early stage.
} 
goods and services, mainly in the developing countries(see de la Garza 2001:697). Others argue for divergence arising from the weakening of national level bargaining systems resulting in diverging regional patterns (Locke 1992), or that ER systems are so strongly institutionalized in wider business system that have their own logic in particular societies making convergence unlikely (Whitley, 2000). Finally, a more nuanced view is given by and Frenkel and Peetz (1998) and Katz and Darbishire (2001). The former authors argue that the trend towards convergence or divergence is mediated by several factors including national industrialization strategies, national culture, and the role of the state, and that in the current period globalization is promoting convergence although the obstacles to its realization are significant. Katz and Derbishire (2001) advocate a position they term converging divergences -- increased variation (divergence) within each country in terms of employment patterns, co-existing with increased similarity of four patterns of workplace practices in advanced countries.

By focusing on the logics underlying ER institutions and processes, our argument integrates both debates. This permits us to understand how ER systems change, either towards convergence or divergence. We argue that employment relations patterns reflect the interplay of three distinct logics of action---the logic of industrial peace, the logic of competition (associated with, but not confined to globalization), and the logic of employment-income protection. Variations in the relative strength of these logics are caused by the economic development strategies, the intensity of globalization, government responsiveness to workers expectations, labor market characteristics, and the strength of unions. Variation in the strengths of different logics, and different combinations of logics, result in variable ER patterns at national, industry, or workplace levels. The logic of competition encourages convergence, while the other two logics promote divergent tendencies. 
The evidence in support of our argument regarding logics of action and ER patterns is based on extensive field research in four major Asian countries: China, India, the Philippines, and Malaysia. We demonstrate that logic strengths change over time in each nation, and that the ER patterns based on our research conform to different combinations of logic strengths in each country.

\section{THREE LOGICS OF ACTION AND PATTERNS OF EMPLOYMENT RELATIONS}

We use the term employment relations pattern to denote a mix of ER policies and institutions at the national level and institutions and practices at the industry and workplace levels. Our focus is to understand the logics underlying the development of these patterns. Drawing from institutional theory, we see logics of action as underlying constructs driving important decisions. Barley and Tolbert (1997), for example, refer to logics as sensemaking constructs that embody conventionalized understandings about what is appropriate and reasonable, thereby shaping actors' strategies. Actors in ER (government officials, employers, and workers) take action and justify their decisions with reference to an underlying logic. An understanding of the strength of different logics in action, we argue, is necessary to understand why certain patterns of employment relations exist, and helps explain future changes in these patterns.

The basic idea is that each logic results in the development of rules and institutions about employment relations. When new logics are introduced, the new logic leads to new rules and changes in institutional arrangements, although the old system is rarely completely replaced. More often, old institutions are reformed in terms of the new logic. For example, the tripartite arrangements that were created in Singapore to guarantee industrial peace have been used in recent years to strengthen the logic of competition. The operation of a particular logic 
can over time have unintended consequences that lead it to lose social relevance. Demands for change in the system are often legitimated by reference to a newer logic. Thus a crucial aspect of our argument is that the relative strength of the logics tend to vary over time within and across nations, and that the different combinations of these logics account for similarities and differences in ER patterns and tendencies to converge or diverge.

This logics of action framework argument can also be derived deductively from a sociological conception of capitalism that assumes conflicts of interest between capital and labor and a system stabilizing role for the state. Thus, capital seeks to maximize profits by securing maximum discretion in allocating and directing labor. At the level of social action, this means taking initiatives in accordance with the logic of competition. Labor, on the other hand, attempts to limit employer action that adversely affected workers' ability to generate a continuing stream of socially acceptable, extrinsic and intrinsic rewards. This is defined as action in accordance with the logic of employment-income protection. Tension or actual conflict between managers and workers preventing either or both parties from attaining their goals is likely to lead to an imposed or negotiated solution. A framework for such initiatives may be introduced by the state. Thus, action in accordance with this tension-reducing or conflict-resolving objective is referred to as the logic of industrial peace. Thus, the different logics of action denote strategies guided by values regarded as especially important by the dominant actors. Below, we discuss these logics in greater detail.

\section{Logics}

We start with the logic of industrial peace since it features prominently in the emergence of employment relations systems (Kuruvilla and Mundell, 1999). Following struggles for independence, ex-colonial countries (e.g. India and Malaysia) recognized trade unions and established tripartite and bipartite bargaining and arbitration bodies. Centralized wage 
determination was an attempt to take wages out of competition. Restrictions on the right to strike were introduced, and in some cases, the subjects of bargaining were restricted (DeSouza, 1999, Hiers and Arudsothy, 1999). Thus, the focus of ER policy was to limit industrial conflict in the interest of economic development. In many of these countries, governments adopted economic developments strategies based on the import substitution industrialization (ISI) model. This curbed internal and external competition through licensing regulations and protectionist tariffs to assist local industry, and helped sustain industrial peace in many countries (Kuruvilla, 1996). In other cases like Singapore, the government emphasized industrial peace as an incentive for foreign investors. A tripartite ER system was created in order to ensure this objective was attained (Chiang, 1988). This was a common "binding constraint" at the time of the inception of ER systems in many developing countries (Kuruvilla and Erickson 2001) and with subsequent industrialization meant that legislation and public policy aimed at preventing and resolving industrial conflict continued to be relevant.

The pursuit of economic development based on export-oriented industrialization (EOI) including increased foreign direct investment and market liberalization policies in many Asian countries (e.g. as in India and China) has led to the ascendancy of the logic of competition. This became most transparent in the 1980s and 1990s as globalization gathered pace (Kuruvilla and Erickson 2001). The rationale of ER under this logic is the facilitation of enterprise efficiency, both in terms of labor market flexibility and labor productivity. A range of policies and practices are typically associated with this logic. For example, competition fosters decentralized decisionmaking aimed at tailoring wage levels to the particular economic environment of firms, rather than industries, hence decentralized wage determination. With an emphasis on cost containment, many managers come to see trade unions as unnecessary impediments to efficiency, hence the adoption of practices designed to marginalize or eliminate these 
organizations. Export processing zones that are exempt from national labor legislation are often established in developing nations to achieve these goals (e.g., Philippines and Sri Lanka). Governments may also use selective immigration as a means of ensuring an adequate and flexible supply of labor (e.g., Singapore and Malaysia). Where competition is based on quality and innovation rather than solely on cost, employers and governments are likely to stress the importance of training in order to improve workers’ competencies, particularly where labor shortages occur.

Rapid industrialization is often accompanied by disruption of extended family support systems, increasing dependence on industrial work, and later, demands for participation in the political system. Increasing competition, and the unrestrained, and often unpredictable, movement of capital, lead to rising job insecurity and unemployment. The employment policies of multinationals and their suppliers contrast with those in smaller, local firms who cannot afford the higher incomes and welfare provisions provided by their new competitors. These developments most often occur against the backdrop of very limited state social welfare provision (e.g., India). Thus, in developing countries most exposed to globalization, there is often rapidly growing support for the logic of employment-income protection. This is manifested in demands for increased worker protection against lay-offs, long working hours, poor health and safety conditions, discrimination, and protection against arbitrary management power. $^{2}$ There are also demands for a living wage, unemployment pay and pensions. This logic, promoted by employees and trade unions, and by human rights groups and NonGovernment Organizations intent on ensuring that large multinational firms act in a more socially responsible manner (Klein 2001). Wider political demands also occur, usually when

${ }^{2}$. This logic underpins both defensive and offensive actions. It includes employer resistance against employee norms and attempts to improve employment stability, rewards and career opportunities. In the context of developing 
industrialization has created a coherent working class. Threats to prevailing standards of living, such as the 1997-98 Asian Financial crisis, can provoke political action. Thus, a more democratic and responsive state has emerged in countries like Indonesia, Thailand and South Korea in recent years. This logic has also been used by governments to take pre-emptive action to limit potential political instability and maintain working class support. This is especially evident where the class-consciousness and power of urban workers has increased (Malaysia) or is growing rapidly (China).

Thus, the logic of Employment-income protectionrepresents workers' responses to employment instability and employer control. It aims to alleviate labor market and managementimposed hardship on workers through rules limiting labor market flexibility and employer discretion, or through the provision of social safety nets via unemployment insurance, funds for retraining, and social security. Typical protections include tripartite or bipartite agreements that promote the role of unions in collective bargaining, and regulation of substantive issues.

\section{Factors Influencing Logic Strength}

The strength of the above three logics vary over time within each nation. We use our four cases to identify critical factors affecting logic strength. We find that five factors appear to influence the strength of the three logics. These are economic development strategies, globalization intensity, government responsiveness to workers' expectations, the state of the labor market, and union strength. We briefly discuss each factor in turn. Before doing so however, it is worth noting that these five factors may be supported or counteracted by industry or firm-specific factors. For example, the employment relations policies of American multinationals in the athletic footwear industry in China has a strong E-I logic, mainly in 
response to the influence of human rights campaigners (Frenkel 2001). Another example is the Philippines refrigerator industry, where ER practices reflect a strong competitive logic, encouraged by the Montreal protocol on limiting chlorofluorocarbons in refrigerator production. Also note that although each factor exerts independent effects on logic strength, they can work together as well.

Where a government pursues an economic development strategy based on ISI, the logic of industrial peace is likely to be strong. The aim is to produce locally instead of importing to conserve foreign exchange, thus increasing local employment and stimulating local investment. However, the success of ISI depends on shielding infant industries from foreign competition, through tariffs. Protection from competition sustains highly protective labor legislation. In contrast, the adoption of an export oriented industrialization strategy, or a less comprehensive policy of opening the economy to foreign investment and trade, will be associated with a strong logic of competition. This arises from an increase in competition -- local employers will now have to compete with foreign multinationals in the domestic economy and in international export markets.

The strength of different logics is also influenced by the intensity of globalization, a term that refers to a country's length and depth of exposure to foreign trade and investment. Other things being equal, the logic of competition is likely to be stronger in countries that have been exposed to globalization for longer over a wider range of sectors. As an illustration of cross-country variance in the intensity of globalization, using four indicators, Table 1 shows that Malaysia and the Philippines are more intensely globalized than China and India. ${ }^{3}$ Note

\footnotetext{
${ }^{3}$. Table 1:Foreign trade, foreign direct investment and annual GDP growth, India, China, Malaysia and the Philippines, 1980-97
} 
also that Malaysia and the Philippines have had a much longer exposure to the international economy, having adopted EOI strategies in the 1970s compared with China and India which started on this course more recently -- China in the late 1970s and India in the early 1990s. China currently receives more foreign direct investment than any other developing country and is fast approaching Malaysia in the contribution of foreign investment to the country's economy.

Motivated by the logic of competition, intense globalization encourages large-scale industrial restructuring that causes employment insecurity, unemployment and sometimes political instability. In this way globalization may serve to increase the strength of the logic of employment-income protectionand if conflict prevails, this may encourage major reforms of ER institutions underpinned by the logic of industrial peace. South Korea is a case in point. Thus, the impact of globalization is likely to be complex and contingent, and changing over time.

A third factor that influences the strength of different logics is government responsiveness to workers' expectations. Where governments are more responsive to the demands of capital, we can expect the logic of competition to be strong. This is especially

\begin{tabular}{|c|c|c|c|c|c|c|c|c|}
\hline \multirow[t]{3}{*}{ Country } & \multicolumn{2}{|c|}{$\begin{array}{l}\text { Exports as a } \\
\% \text { of GDP }\end{array}$} & \multicolumn{2}{|c|}{$\begin{array}{l}\text { Imports as a } \\
\% \text { of GDP }\end{array}$} & \multicolumn{2}{|c|}{$\begin{array}{l}\text { Inward FDI as \% } \\
\text { of Gross Fixed } \\
\text { Capital Formation }\end{array}$} & \multicolumn{2}{|c|}{$\begin{array}{c}\text { Outward FDI } \\
\text { as a \% of } \\
\text { Gross Fixed } \\
\text { Capital } \\
\text { Formation }\end{array}$} \\
\hline & 1980- & $1990-97$ & 1980-89 & $1990-97$ & 1980-89 & $1990-97$ & 1980- & $1990-$ \\
\hline & 89 & & & & & & 89 & 97 \\
\hline India & 6.4 & $9.4^{* 1}$ & 8.5 & 10. $*^{1}$ & n.a. & $1.9 *^{2}$ & n.a. & $0.2^{* 3}$ \\
\hline China & 10.1 & 18.8 & 11.6 & 17.2 & 2.0 & 11.1 & n.a. & 1.1 \\
\hline Philippines & 24.7 & 34.7 & 26.3 & 41.6 & 3.9 & 8.0 & n.a & $0.2^{4}$ \\
\hline Malaysia & 58.1 & 86.0 & 55.6 & 86.4 & 10.3 & 17.6 & n.a. & n.a \\
\hline
\end{tabular}


evident in Singapore and Philippines, where government employer coalitions are strong. Where governments are also dependent on industrial workers to remain in office -- as in India, and Malaysia, we can expect concessions based on the logic of Employment-income protection. Efforts to prevent industrial instability also occur through the development of ER frameworks that permit worker representation through independent unions. On the other hand, where governments are based on a single party that monopolizes power -- as in China or Vietnam -responsiveness to workers' interests is likely to be lower, despite rhetoric to the contrary, and so we anticipate a weaker logic of Employment-income protectionin this case.

A fourth factor that affects the strengths of different logics concerns the state of the labor market. Tight labor markets, for example, encourage governments to pursue human resource development strategies placing more emphasis on skill upgrading and functional flexibility within firms, as Kuruvilla and Chua (1999) show in their study of Singapore. This arises because it becomes more difficult to compete on the basis of low cost, low skilled labor where labor markets are tight. Government policy can also encourage employers to adopt more advanced human resource policies in order to more effectively motivate and retain skilled workers who have a propensity to move between firms in search of improved pay and conditions. Thus, tight labor market conditions tend to increase the strength of the logic of Employment-income protection. Although China, India, and the Philippines have surplus labor in most, but not all occupational categories, Malaysia has experienced more widespread, chronic labor shortages, and a relatively sdtronger logic of employment-income protection. So has India's software sector, where there is a focus on functional flexibility and favorable pay and conditions i.e. a relatively strong logic of employment-income protection.

The fifth and final factor that affects the strength of different logics--- union strength. Is also related to the state of the labor market. Where labor markets are tight, unions may form and 
bargain more easily ${ }^{4}$. This will result in a stronger logic of Employment-income protectioncompared to industries or countries where labor markets are characterized by labor surpluses. In general, where the state is more sympathetic to unions, enabling them to engage in bargaining and political activity, we expect a stronger logic of Employment-income protection. In this regard, India, particularly prior to economic liberalization, was comparatively strongly unionized. This was due to the close link between unions and political parties. Our three other countries lacked one or more of these conditions. For example, in Malaysia, unions are relatively constrained by legislation, however, workers' interests are taken seriously by the government. In the Philippines, unions are relatively free (although very weak given excessive fragmentation) and the government appears much less concerned with workers' interests. In China, independent unions are not permitted and despite the government taking some interest in workers' welfare, these government policies are not rigorously enforced. Thus, other things equal, strong unions will be associated with a strong Employment-income protection logic. Relationship between Logics. The three logics discussed above rarely operate alone. At least two of the three logics tend to be present in varying degrees of strength in all industrializing societies, depending mainly on the impact of the factors discussed earlier. The relations between logics may be contradictory or reinforcing. For example, the logic of industrial peace may contradict the logic of competition, if union strength, facilitated by a collective bargaining framework, is used to limit innovation and organizational change. On the other hand, these two logics may reinforce one another, if, by maintaining industrial stability, union strength leads to additional investment and earnings growth. Similarly, the logic of Employment-income protection is likely to support the logic of industrial peace since workers with better wages and conditions are less likely to engage in disruptive collective action. On the other hand, this logic

\footnotetext{
${ }^{4}$ Note that other factors, such as protectivelegislation, political linkages, also influence union strength.
} 
may contradict the logic of competition if employment stability limits numerical flexibility and sustains higher labor costs. However, the logic of employment-income may reinforce the logic of competition by promoting functional flexibility in firms competing on quality and innovation. In short, the impact of the interactions between various logics cannot be understood apart from the context in which those logics operate.

\section{Logics, Employment Relations Patterns, Convergence, and Key Propositions}

Several ideal type ER patterns resulting from the dominance of each of our three logics can be identified. Acknowledging that there is variability in the strength of each dominant logic, we offer a strong and weak variant in each case. These ideal types provide benchmarks against which our findings can be compared.

Where economic conflicts of interest are generally accepted (as in liberal capitalism in contrast to fascism and communism) and the logic of industrial peace is strong, we expect an ER pattern regulated by a tripartite or bipartite framework. Laws will exist to protect trade union formation and bargaining, and there will be specific institutional mechanisms exist for the resolution of various kinds of industrial disputes. There is likely to be little or no gap between practice and policy.

An alternative strong industrial peace scenario is one where the state outlaws industrial conflict and independent unions and imprisons workers who undertake industrial action. Industrial conflict in such situations, is likely to be channeled into other forms of behavior including pilferage, sabotage, a large number of grievances, and labor turnover.

It is also possible a strong industrial peace logic may be institutionalized in a weak manner...i.e. where the gap between practice and policy is wide -- the rhetoric of tripartism or bipartism is not supported by commitment to, and enforcement of relevant laws and agreements, and union may only have the power to bargain successfully in a limited number of sectors. 
A strong logic of competition is likely to be associated with an ER pattern whose institutions and rules make it difficult for trade unions to form and bargain freely, or and are likely to confine such activity to a limited range of issues at the enterprise level . Employers, on the other hand, in this pattern are given considerable freedom to pursue practices aimed at increasing numerical and wage flexibility. These practices include use of casual workers and being able to lay off workers relatively easily, and varying pay according to output. Alternatively, competitive advantage might be sought through an ER pattern that emphasizes functional flexibility, namely a high-wage high skill approach. In this pattern the government may invest heavily in education and training and encourage firms to do the same.

However, this high skill-high wage option is less likely in developing countries whose comparative advantage lies in exploiting their low labor cost advantage. A weaker variant of the logic of competition would entail less support by the government for so-called free labor markets and some employee protection against arbitrary management action. Redress is likely to be through the courts rather than through trade unions, which the government and employers are likely to discourage.

A strong logic of Employment-income protection is likely to be associated with an ER pattern supported by effective legislation providing for minimum wages, health and safety, hours of work, and social welfare - especially unemployment benefits and pensions. Employees are also likely to receive some protection against loss of employment (through lay-offs, dismissals or redundancy) and support for skill formation, consistent with favoring functional over numerical flexibility. In some variants of this pattern, government supports collective bargaining over a range of substantive matters, although governments can be expected to limit union power if unions are seen as a source of political opposition. A weaker variant would be less effective in 
implementing relevant laws, a lower level of support for trade unionism and skill formation, and less comprehensive coverage of issues of concern to workers.

Finally, it is important to examine how the three logics relate to the convergence and divergence of employment relations systems. The logic of industrial peace is likely to be a force for divergence. Different combinations of policies and practices that derive from unique national institutional histories can be (and are) used to provide industrial peace. By contrast, the logic of competition represents a force for convergence, as it brings with it a relatively uniform focus on flexible labor markets and pursuit of best practices often promoted by global consulting firms. In developing countries that adhere to the logic of competition, the emphasis will be mainly on numerical and wage flexibility. Note however that policies aimed at increasing flexibility may be adopted at varying speeds. The spread of adoption will be affected by institutions, rules and attitudes that retard change. In addition, supra-national, and regional regulation, as in the case of the European Union - can stimulate national employment systems will converge.

The logic of employment-income protection is likely to be a force for convergence and divergence. It will be a force for convergence in terms of certain basic minimum standards, given their absence in some countries, and given the pressure of the developed world in linking common labor standards to trade. Beyond core minimum standards, however, policies under this logic will cause divergence. Our contention is that as a reaction to the negative impacts of globalization, workers will tend to demand protection from the uncertainties produced by intensified competition. This is likely to lead to policies and practices that confer basic entitlements -- minimum standards in relation to pay and employment conditions. Above these minimum provisions, there is likely to be cross-country as nations craft different policies to meet local demands for employment and income protection. 
The framework developed above yields the following five propositions that can be assessed with our case examinations of developments in India, China, Malaysia, and the Philippines.

1. The relative influence of the three logics will vary in the four countries.

2. The strength and importance of each of the logics of action will depend on particular economic and social circumstances, notably, the national economic development strategy, the intensity of globalization, the government responsiveness to employee expectations, the state of the labor market, and union strength.

3. The differing strength of the logics of action in each country leads to international differences in ER patterns.

4. The interplay between different logics is key to understanding globalization's impact on employment relations.

5. A dominant logic of competition will produce ER pattern convergence, while ER patterns will tend towards divergence when the other two logics dominate.

\section{METHODOLOGY AND DATA}

Empirical research was conducted in India, China, Malaysia, and the Philippines in 19981999. These are not a representative sample of Asian countries. Rather, they were chosen because of their importance to the Asian economic region and because they reflect the diversity that is typical of Asia. This countries differ in terms of size, institutional history, and exposure to globalization. This variation provides a broad test of our framework, and a platform to examine globalization's impact.

Our research aims at describing and understanding the main employment relations policies and practices that characterized each of the four countries. We also seek to understand 
the factors and processes encouraging change in employment relations. In each country we first examined changes in ER policy at the national level through an analysis of secondary sources, interviews with the principal industry associations, and in some cases, with government officials. We then selected a subset of industries and firms based on four criteria: exposure to international competition; importance of the industry to the national economy; industry mix -- to ensure coverage of both manufacturing and service industries; and finally, enterprise nationality, i.e. we included both dominant, foreign-owned and domestic companies.

In order to understand recent developments in leading industries in the four countries, two to three lead firms were selected in key industries and studied in detail. This involved our research teams (comprising two to three persons) reviewing industry-specific data, conducting interviews with industry associations, and spending approximately one day observing a workplace. Interviews were undertaken with human resource (HR) managers, union leaders and workers. In total, we studied 13 industries and 54 firms, though the firms were not always associated with the same industries in the four countries. We studied the electronics/information technology (IT) industries in all four countries (12 firms) and the banking sector (12 banks) in three out of the four countries (China excepted). The consumer goods sector was explored in the four countries, however, because the importance of different kinds of consumer goods varies between the countries, we studied different consumer goods industries in each country: For example autos and refrigerators in India and the Philippines (8 firms); motorcycles in India (one firm); autos in Malaysia (five firms); hotels in India, Malaysia, and China (6 hotels); athletic footwear in China (2 firms); textiles in China ( 2 firms); toys in china (one firm); food processing in China (one firm), sugar and petroleum (2 firms) in the Philippines, and pharmaceuticals in India (four firms). 
Several caveats regarding the data should be noted. First, although the data were collected according to an agreed template by experienced researchers, this is not a statistically representative sample of firms. Rather, the data indicate ER changes in lead firms in important industries. The firms we researched tended to be larger, higher paying, more law-abiding companies, and more highly unionized than the average company in any of the four countries in our study. This limitation needs to be seen in the light of the scarcity of comparable data and the difficulties (including costs) of obtaining valid and reliable data in smaller firms in developing countries. Further, although we attempted to get a mix of both foreign-owned and domestic firms, in some countries (notably China), most of the firms were foreign-owned.

Another noteworthy point is that the research was conducted in the immediate aftermath of the Asian Financial Crisis. This probably biased our results towards a stronger emphasis on the logic of competition, especially in Malaysia and the Philippines, than might otherwise have been the case. However, the Crisis highlighted the ongoing volatility of financial movements and ad hoc international regulation, so we would not alter our conclusions. Finally, since our purpose here is to interpret our case study evidence using the logic of action framework, we refer to general ER patterns that derive from our cases rather than specific details. ${ }^{6}$

\section{EVIDENCE FROM THE FOUR COUNTRIES}

\section{India}

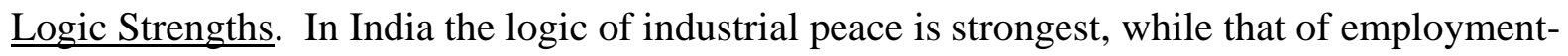
income protection is also quite strong. The evidence for this is as follows. The framework of labor law and some central government policies continue to be dominated by a preoccupation

\footnotetext{
${ }^{6}$ More detailed descriptions and analysis can be found in our ILO project publications as follows: Chiu and Frenkel 2000; Hiers and Kuruvilla 2000; Kuruvilla et al. 2000; and Peetz and Todd 2000.
} 
with preventing and settling industrial disputes. For instance, Indian labor law still requires government permission for layoffs (which are only allowed for 180 days with compensation), and for retrenchment and workplace closure. Dispute resolution mechanisms still require that strikes be withdrawn when conciliation begins (Hiers and Kuruvilla 2000, Venkatratnam 1993). To alleviate the negative employment effects of restructuring, a National Renewal Fund was established in 1997 to provide counseling and job training, the first step in an active labor market policy that is likely to be deepened (Venkatratnam and Naidu, 1999).

Although the economic development strategy has shifted from ISI to a more liberalized economy since 1990, only in May 2001 did the BJP government announce plans to change labor legislation to promote workplace flexibility. ${ }^{7}$ although this announcement was accompanied by a policy to increase separation benefits, in line with an employment-income protection logic.

Note however that globalization in India is still at an early stage and has yet to gather

momentum: exports and imports as a percentage of GDP are still below $10 \%$ and inward foreign direct investment in 1997 was less than 2\% of gross fixed capital formation.

Indian trade unions, despite their relatively low density, continue to be influential ${ }^{8}$. This reflects their links to political parties which enable union leaders to influence voting in local and national elections especially among swinging voters in sectors where they remain strong, most notably the public sector (Venkataratnam, 1993). In addition, the unions and their political supporters have maintained legislation protecting employees in the formal economy from layoffs

\footnotetext{
${ }^{7}$ The BJP government has said that it would alter the Industrial Disputes Act to apply to organizations employing more than 1000 workers only (it used to be 100 before). This would make it easier for these organizations to layoff workers and close without prior government permission. However, no legislation has yet been introduced.

${ }^{8}$ Union density estimates in India are notoriously unreliable (Das 2000). Estimates vary depending on the basis of calculation, ranging from $2.6 \%$ of the non-agricultural workforce, to $38 \%$ of wage and salary earners, to $75 \%$ of the formal industrial workforce (large private and public sector firms).
} 
and dismissals, and from other arbitrary management action. ${ }^{9}$ In this way, the logic of employment-income protection has been sustained.

Although the logic of competition is still relatively weak in India, several indicators suggest that it is becoming stronger. One indicator is declining union density and associated with this, waning union power. Liberalization has driven a wedge between organized labor (who favor the continuation of an ISI-oriented development strategy) and political parties (who favor economic liberalization). Union power is also declining on account of the rise of businessgovernment coalitions at the state level.

A couple of states have changed their labor laws to make it easier for employers to deal with unions, an important issue in attracting foreign investment. For example, Maharashtra has rationalized union recognition procedures to facilitate a single bargaining agent in each workplace, a policy that was long resisted by unions who preferred having multiple bargaining agents. The state government of Kerala has guaranteed a no strike period for foreign investors and banned work stoppages in certain industries (e.g construction). The state of Uttar Pradesh has signaled its support for employers by mandating that government factory inspectors may enter factories for inspection (to check if labor standards are violated) only after receiving permission from the district magistrate.

Furthermore, restructuring has reduced employment (through the operation of voluntary retirement schemes), and increased subcontracting, both of which have taken their toll on the unions. These too reflect the increasing importance of the logic of competition.

In sum, India exhibits a continuing strong logic of industrial peace, with a weakbut rising strength in the logic of competition and a relatively weak logic of employment-income

\footnotetext{
${ }^{9}$ The Industrial Employment Standing Orders Act lays out a very highly developed due process procedure for terminations of employment in the case of misconduct, and the law requires that firm level policies on punishments
} 
protection. Clearly, the change in economic development strategy in India has strengthened the logic of competition in India, but strong unions, and a government responsive to workers concerns continue to ensure that the logics of employment-income protection and industrial peace remain strong.

ER Pattern. The combination of the relative strengths of the logics referred to above can be seen in ER policy and practice. We noted that central government legislation has not changed very much. It continues to reflect a concern with industrial peace and Employment-income protection. Meanwhile, state governments and employers are pushing for labor law reform and the current ruling BJP (Bharatiya Janata Party) government has just announced in May 2001 its intent to change labor law to permit layoffs and retrenchment for a larger set of workplaces than before. These actions underpin the emerging logic of competition. There is more evidence of the logic of competition at the workplace level. ${ }^{10}$

In the more complex consumer goods industries, such as autos, and electronics, the dominant managerial focus is on functional flexibility with some efforts to link compensation to skills acquisition and an emphasis on training. In the consumer goods sectors making simpler goods such as household appliances, the focus is clearly on cost containment and numerical flexibility. In these sectors, the dominant management strategy was to establish non-union, greenfield sites far away from urban locations where union activity is concentrated. This is particularly evident in the domestic appliance sector where the major players (one joint venture and one MNC) combined old, so-called brownfield factories located in urban areas, mainly employing unionized, semi-skilled workers on repetitive jobs with new greenfield plants. These use non-union, more skilled workers employed more flexibly, while at the same time relying on 
subcontractors and temporary workers for numerical flexibility. This pattern differs from that of the domestically-owned hotel industry, which has experienced chronic shortages of skilled employees, and emphasizes functional flexibility.

In the banking sector, where nationalized enterprises account for $80 \%$ of market share, there are few signs of change towards flexible practices, given strong and militant unions with a long record of success at industry wide collective bargaining. The employers wish to emulate their foreign counterparts who are being encouraged by the central government. Foreign banks had introduced team systems and functional flexibility. More generally, many firms across a variety of industries were beginning to introduce new forms of work organization that included teams, performance-related or skill-based pay, and supporting appraisal systems. Worker training is receiving increased attention, particularly in the software industry which has been experiencing chronic labor shortages. In most sectors, firms had recently reduced their headcount. This has been accomplished through negotiated voluntary retirement programs, for as we have noted, it is difficult to lay off or retrench workers in India. While labor-management relations remain conflictual, employers are successfully avoiding strikes by pursuing aggressive anti-union strategies which include increasing the number of non-union workplaces as indicated above. This is a significant departure from the pre-liberalization period.

In sum, the Indian case illustrates the persistence of past patterns dominated by the logics of industrial peace and Employment-income protection. These logics and their attendant institutions and rules were developed in the context of an import substitution industrialization development strategy and the continuity of a union movement that was part of the Indian independence movement with strong linkages to political parties. On the hand, the logic of

${ }^{10}$. This is based on our research in the following industries: hotels, automobiles and motorcycles, domestic appliances (refrigerators and washing machines), electronics, software, pharmaceuticals, and banking. 
competition is clearly on the ascendant, particularly at the workplace level where efforts to increase functional and numerical flexibility vary according to firm and local union characteristics (Bhattacharjee 1999; Hiers and Kuruvilla 2000), but are nevertheless gathering steam. The Indian ER pattern is thus unstable, with opposing logics limiting change and posing dilemmas for employers and unions. When changes in labor legislation do occur, this is likely to accelerate tendencies already under way.

\section{China}

Logic Strength. In China, the logic of competition is strong and dominant and although the logics of industrial peace and Employment-income protectionremain weak, they are increasing in strength. The two most important factors influencing the strength of logics in China have been changes in China's economic development strategy and globalization. Prior to the transition from a centrally planned economy based mainly on import substitution to a guided market economy open to foreign investment in the late 1970s, the so-called iron rice bowl system prevailed. Under this system, employees were allocated to state-owned enterprises (SOEs) which guaranteed lifetime employment and a wide range of benefits, including housing and education. Wage levels were set centrally and the Party played a supervisory role in the factory. Changes in employment relations in the 1980s began to align the emerging pattern with a market economy. Measures were undertaken in order to improve SOE competitiveness and to ensure that firms with foreign investment (initially joint venture and more recently, wholly-owned foreign companies) could operate without undue state interference. Accordingly, centralized job allocation and state guarantees of lifetime employment were relaxed and firms were no longer required to provide social welfare benefits; these began to be gradually shifted to regional authorities. In 1986 changes in the law required that new workers be hired on fixed-term contracts with a maximum duration of four years (which was not sanctioned by local authorities 
and implemented systematically until the early 1990s) and workers could be dismissed under certain circumstances. The authority of the factory director was enlarged and the power of the party in the enterprise downgraded as part of a move to "market-oriented" management. Enterprises were also encouraged to link rewards to performance through the use of bonus systems (Child 1994: 163-64). In the case of joint ventures with foreign firms, labor contracts were already encouraged in the 1979 joint venture law and in an effort to limit pay relativities, a 1984 regulation required foreign-invested enterprises to pay between 120 and 150 percent of local enterprises in the same industry (though this does not seem to be followed consistently).

In the early 1990s new regulations permitted managers to lay-off surplus workers either through voluntary retirement (with some assistance in finding these workers new employment), or through retraining. Meanwhile, the government banned independent unions and any form of collective action in industrial disputes. State-controlled unions continued to exist, with structures external and internal to the enterprise. ${ }^{11}$ Industrial disputes in SOEs were acknowledged in a 1987 dispute settlement law that was later extended to foreign-invested enterprises and to a wider range of issues. Arbitration tribunals were also established there. (Seung 2000:51 and 59).

China industrialized rapidly in the 1980s and 1990s, becoming the largest recipient of foreign direct investment of all developing countries and increasingly engaging in international trade (see Table 1). Globalization strengthened the logic of competition in China and encouraged the introduction of a comprehensive labor law in 1994 that consolidated the myriad of laws that had been passed over the previous 15 years. The new law applied to both domestic and foreign-invested enterprises including Foreign-invested firms. Although it was underpinned by the logic of competition, it also reflected the logic of industrial peace and the logic of

\footnotetext{
${ }^{11}$. In 1992 some formal changes were made to trade unions. The right of unions to employ a specified ratio of fulltime union officials to the number of union members was revoked and payment of salaries of these officials was
} 
employment-income protection. For example, the 1994 Act gives state-controlled unions the right to enter into collective bargaining with employers on a prescribed range of matters including wages and working conditions. The ILO has been giving technical assistance on collective bargaining dispute settling procedures. The same Act specifies minimum labor standards regarding wages, hours of work, health and safety, and discrimination against women and young workers.

In sum, formally the three logics are reflected in the emerging legal framework, however as indicated below, the gap between formality and actual practice highlights the dominance of the logic of competition over the other two logics.

ER Pattern. China's ER pattern is difficult to describe because the formal system of laws and regulations is supplemented by local interpretation and is unevenly enforced. For example, provincial differences apply to the application of the Hukou system of worker registration. It is easier for workers to obtain and extend work permits in some provinces than others. A second example is working hours. In several districts of Guangdong province firms are able to extend working hours beyond the 60 hour a week maximum (which includes overtime) by seeking permission from the local government labor authority. This is rarely denied. Provincial and district level officials have sacrificed enforcement of labor standards for attracting investment and generating additional jobs. The logic of competition dominates. This can be seen by briefly examining employment relations at workplace level, in SOEs and foreign-invested firms respectively. $^{12}$

transferred from the trade union to the enterprise. Enterprises continued to deduct two percent of the wage bill for use by the union in the enterprise and were to have access to an office.

${ }^{12}$. SOEs represent a significant, albeit declining sector of the economy. These organizations accounted for $28 \%$ of GDP in 1996 compared with 76\% in 1980 (Schlevogt 2000). In 1990, SOEs accounted for 62\% of employment in urban areas and Foreign-invested firms less than 0.5\%. By 1998, SOEs accounted for $44 \%$ and Foreign-invested firms nearly $3 \%$ (half of the employment being generated by enterprises based in Hong Kong, Macao and Taiwan). 
In order to ensure survival, SOEs have been following a formal strategy of cost reduction and productivity improvement. Young, female workers were employed to undertake relatively low skilled, light manufacturing jobs. There was close monitoring of production with strong worker performance being rewarded with increased pay and weak performance attracting financial penalties. Legal violations of working conditions and dismissals regulations are common. Meanwhile, underemployment remains a problem in SOEs with approximately one third of enterprise workers labeled xiagang (surplus workers) (Chiu and Frenkel 2000). However, job tenure has become convertible to cash (Lee 1999:61-67) and has contributed to increasing unemployment. This emphasis on numerical and wage flexibility, underpinned by the logic of competition is only occasionally counterbalanced by measures based on functional flexibility. ${ }^{13}$

The logic of employment-income protection has not been vigorously pursued by the unions in China. By late 1995 there were less than 11,000 collective agreements (Lee 1999:56) and even in these cases it is unclear to what extent bargaining actually occurred. Interview (Lee 1999: 58) and survey (Seung 2000:62) evidence suggests that Chinese workers have little faith in their unions. Lee (1999:66) speaks of "demoralization on the shop-floor” as workers are squeezed between the state's failure to provide a new social safety net and the demise of the iron rice bowl system. Overall, she concludes that [yet] "these formal improvements stand in stark contrast to the dismal realities of powerlessness among-grass roots union cadres and workers inside SOEs" (p.57). ${ }^{14}$

\footnotetext{
13 . According to Freund (1998), Bao-shan Steel reduced their workforce by over 15000 workers (about 33\% of its workforce) and then focused on functional flexibility strategies in relation to the workers who remained.

14. A less critical picture is given by Sheehan et al. (2000) who claim that SOE managers are generally reluctant to lay-off workers. Various alternatives are used before resorting to redundancy. These include transfers to service jobs or other businesses in the same enterprise and reductions in pay (Sheehan, Morris and Hassard 2000:489.)
} 
Zhao and Nichols (1996:21) draw attention to Chinese workers’ growing consciousness and protests. Thus, between 1987 and 1992 collective labor disputes increased six-fold and according to a local report there were " 14 times more labor disputes -- from simple contractual disagreements to work stoppages and strikes - last year (1999) than in 1992.” (Guardian Weekly May 4-10, 2000:37). ${ }^{15}$ Reports suggest that these seemingly spontaneous actions have been more frequent in outlying provinces less subject to control by Beijing and in foreign-owned (mainly Korean and Taiwanese) enterprises in southern coastal regions such as Guangdong and Fujian (Seung 2000:57; Chiu and Frenkel 2000).

Regarding foreign-invested firms, employment relations reflects a blend of foreign practices with those derived from the iron rice bowl system, hence the hybrid model described by Ding, Fields and Akhtar (1997) dominates. Goodall and Warner (1997) and Ding and Warner (1999) point to continuities with past practices such as the continuation of relatively egalitarian pay differentials, and workers with over 10 years' employment with the same employer continue to be given open-ended rather than short-term contracts.

In the foreign-invested firms we studied, at least 80 percent of each of the factories' output is for export. Although cost reduction is seen to be important, so is quality, training, and a desire to limit labor turnover. One of the footwear companies, which has contracts with a global corporation, is intent on improving its labor practices and uses the global company’s codes of practice as its ER policy document. Like their state counterparts, foreign-invested firms use pay for performance systems, attempting to tie costs closely to output. No union exists at six of the eight workplaces and where a union is present, it mainly performs a social welfare function. These data contrast with an earlier estimate of 36 percent of joint ventures having unions in the

${ }^{15}$. Although collective disputes (in contrast to individual conflicts) comprised only 7 percent in 1998 (the latest year for which data are available), this figure more than quadrupled in the first half of 1999 compared to the same period 
mid-1990s (Chiu and Frenkel 2000). Nevertheless, in contrast to many SOEs, all but one of the eight companies had increased employment recently and are profitable. By and large, these companies paid between 20 and 40 percent more than comparable SOEs. Workers value the benefits and training given by foreign-invested firms - a reflection of the greater emphasis given to the logic of Employment-income protection in the service of retaining a competitive advantage.

In sum, there is considerable variation and flux in China with SOEs mainly pursuing numerical flexibility and cost containment strategies and foreign-invested firms paying more attention to functional flexibility. The logic of competition dominates, although pressure for improved quality and a limited number of qualified employees mean that it is in the interest of employers to also follow the logic of Employment-income protection. At the same time, rising worker protests against unemployment and job insecurity in the SOE sector suggest a growing role for procedures designed to secure industrial peace.

\section{The Philippines}

Logic Strength. Similar to China, the logic of competition is the dominant logic in the Philippines. The other two logics are relatively weak. Regarding the logic of industrial peace, the initial labor policy of the Philippines, modeled on that of the United States, drew heavily on this logic to establish a decentralized collective bargaining system (Kuruvilla and Erickson 2000). This logic changed in the 1960s and 1970s with the adoption of an EOI program. Under President Marcos (1966-1985), this development strategy was used to suppress labor unions and lower costs. The Philippines economy evolved to become one of the most open in Asia with a relatively intense experience of globalization as indicated in table 1 (Villegas 1988, Kuruvilla, 1996). The labor movement remains weak with only 9\% percent of workers (3.6 million) being 
members. The movement is fragmented with 8,822 unions affiliated to more than 174 federations and only 600,000 workers covered by collective bargaining agreements. Union weakness has led to little organized opposition to employer strategies based on the logic of competition. The 1997-98 financial crisis accelerated growing labor casualization, subcontracting, and labor-only contracting in a context of growing unemployment and sharpened divisions within the working class (Kuruvilla et al. 1999, Barranco-Fernando, 1998).

Consistent with the logic of competition, there are widespread anti-union policies by employers and some provincial governors, particularly in the rapidly growing, export processing zones. Furthermore, given the Philippines mediocre economic growth rates over the past 25 years, increasingly, political legitimacy is based on economic performance. ${ }^{16}$ However, popular demands, of both employers and labor, have not been satisfied thereby contributing to political instability.

Acknowledging some of the negative effects of globalization on employees, the Ramos government in the mid 1990s introduced policies that reflect the logic of employment-income protection. These policies include a rejuvenation of tripartism during the Asian financial crisis and a major reorganization of the training system to relieve shortages of skilled workers. These policies have had limited impacts (Ofreneo and Ortiz 1998; Ofreneo 2000). Lamberte, Gurrero and Orbeta (1999) note that the government strengthened the enforcement of separation pay provisions in the labor code, although they suggest that this did not stem worker layoffs. After the crisis, there was some evidence of policies consistent with the logic of employment-income protection, such as emergency loans for displaced workers (the Philippines does not have an unemployment insurance system), subsidized rice, and job creation through the Community

\footnotetext{
${ }^{16}$ Average annual economic growth in the Philippines was -1.7\% in the 1981-85 period, 5.4\% in the $1986-90$ period, and $2.9 \%$ in the 1991-95 period (Kuruvilla et al, 2000).
} 
Development Employment Program focusing on small scale projects (Esguerra, Balisacan and Confesor, 2001). A number of new "passive labor market policies" were adopted, such as establishment of public employment services in every city, a job exchange network, jobs and livelihood fairs, and assistance for displaced overseas workers. On the other hand, violations of labor law remain widespread. Thus, the logic of competition dominates in the Philippines. ER pattern. In terms of government policy, there has not been any major changes in labor law since the end of the Marcos regime. The Aquino regime (1985-1990) only lifted the more blatantly repressive legislation. By and large, labor legislation and enforcement remain consistent with the logic of competition initiated earlier. (Kuruvilla et al. 2000).

Regarding ER practices at the workplace level, our fieldwork reveals two broad types of ER patterns. ${ }^{17}$ One less common type was mainly restricted to US-owned semiconductor factories, where functional flexibility was the goal, with teamwork, pay related to skill acquisition, intensive training, high process and quality standards, and high pay (relative to the rest of the country) as the key work practices. However, none of these plants are unionized, and management aggressively opposes unionization. The same focus on functional flexibility is also evident at one of the automobile factories.

The predominant type of ER pattern focuses on numerical and wage flexibility. Practices include layoffs, use of casual labor, and labor-only contracting (an illegal system where work done by previously permanent factory employees is contracted out). Training by and large is onthe-job in these factories (notably in the second auto factory and the banks), while work organization is Taylorist in character. The banking and petroleum sectors had only been recently deregulated or privatized, and hence there has been a gradual movement towards the adoption of

\footnotetext{
${ }^{17}$. In the Philippines our research was based on two refrigerator factories, three electronics factories, three automobile factories, 3 banks, and one factory each from the sugar and petroleum industries.
} 
more "competitive" ER practices, particularly sub-contracting. This movement has been more benign in banking, particularly given that the largest bank (the Philippines National Bank), owned by the government has been making minor changes to its traditional employment practices.

In terms of labor relations, while the electronics factories avoid unions, in the five of twelve unionized workplaces, union power had diminished as a result of layoffs during the 199798 financial crisis and on account of greenfield site strategies adopted by management. This is particularly the case in the refrigerator sector where employers are intent on reducing costs arising from increased worker compensation premiums and the Montreal protocol that requires elimination of chlorofluorocarbons in refrigerators. In those factories with established labor relations the focus is on collaboration in order to compete more effectively. Management introduced labor-management councils, however it is too early to gauge their impact.

In sum, changes in the Philippines ER pattern reflect intensification of the competition logic with employers pursuing cost-reducing strategies without much legal restraint in a decentralized ER system. The logic of industrial peace remains strongly inscribed in the law and in the institutions of the decentralized bargaining system. However, it has little operational relevance today. The logic of Employment-income protection also remains weak as it is viewed as an additional cost that might discourage foreign and domestic investment. Meanwhile, the weakened unions have not been able or willing to resist the competitive logic and close the gap between rhetoric and reality in regard to protecting workers' interests.

\section{Malaysia}

Logic Strength. In Malaysia, the logic of competition dominates the other two logics. Although the logic of industrial peace continues to exist, it is declining in significance while the logic of employment-income protection, although relatively weak, has been increasing in strength. In the 
1950s, and for most of the 1960s, Malaysia pursued an ISI strategy. In order to prevent and resolve industrial disputes that had little reference to external market pressures, Malaysia established an elaborate ER system based on restricted collective bargaining (Hiers and Arudsothy, 1999). Unions were permitted, however, they were excluded from political activity and were not permitted to bargain on employee transfers, promotions, job assignments, and layoffs. In addition, unions were legally entitled to strike only under very limited conditions. In the 1970s the government switched to a low cost EOI strategy. This was accompanied by measures to contain costs, including a ban on unions in electronics, the major exporting industry(Kuruvilla 1996). Notably, the government has consistently refused (and continues to do so), the enactment of a minimum wage law (Mansor et al, 2000).

Later, in the 1990s, the adoption of a more capital-intensive EOI strategy predicated on increased foreign investment, further strengthened the logic of competition. It did so in two ways. First, it encouraged the government to introduce a national human resource development policy in order to develop the skill base to support production of more complex products for export. Second, under international pressure, the government lifted the ban on electronics unions in 1988, however, it acted to reduce union power by amending the Trade Union Act of 1959 to facilitate enterprise rather than industry unions, and thwarted merger efforts by public and private sector union federations. These actions were consistent with the logic of competition that favors managerial prerogatives and government support of employers. 
With a union density of only around $11 \%$, Malaysian unions have been unable to promote legislative action countering the logic of competition, especially given the sustained success of the Malaysian economy (until recently) shown in Table 1 for which the government claimed credit. ${ }^{18}$ Malaysia's rapid economic growth however has resulted in chronic labor shortages. . Thus, in the late 1980s the government introduced a guest worker program that resulted in foreign workers accounting for around 15-20\% of the workforce (Hiers and Arudsothy, 1999). Thje onset of the Asian financial crisis has increased the strength of the logic of competition. The government has responded to the crisis in two main ways. The first way is to concentrate employment instability mainly among foreign workers The proportion of foreign workers has declined (though no precise figures are available) as many guest workers did not have their contracts renewed in the aftermath of the financial crisis (Mansor et al 2000). A second government approach to labor shortages has been to emphasize functional flexibility (in fact, government action in this regard pre-dated the Asian financial crisis). The policy has emphasized skills development through various measures, most notably a human resource fund (modeled on the skills development fund in Singapore) that requires corporations to pay a certain percentage of their payroll to the fund. Corporations receive refunds of up to $80 \%$ of their investment in training. More generally, the government has protected Malaysian workers from lay-offs and dismissals. The Employment Act 1955 requires 10 days retrenchment pay per year of service for employees with less than two years' service, and 20 days per year for those with three or more years of service. Most employers give one month's retrenchment per year of service. Companies are also required to give one month’s notice to the Ministry of Human Resources who usually attempt to prevent or limit lay-offs consistent with the government's Code of Industrial Harmony

\footnotetext{
${ }^{18}$ In 1998, reflecting the impact of the Asian financial crisis, the Malaysian economy contracted by $7.4 \%$. In 1999 GDP increased by 5.8\% and in 2000 growth had accelerated to 8.5\% (ADB 2001).
} 
which has been referred to in judgements by the Industrial Court.

In response to growing hardship occasioned by the financial crisis, the government invited the Malaysian Trades Union Congress to join a committee charged with developing a national economic recovery plan and the Congress's officials served on a subcommittee of the tripartite National Labor Advisory Council established to draw up guidelines on the handling of retrenchments. To support the measures on using retrenchment only as a last resort, the government agreed to reimburse employers $100 \%$ of the costs of training, if they were sent for training during the financial crisis, instead of being retrenched (Mansor et al, 2000). Various other employment and income maintenance programs, direct and indirect, were introduced during this period (see Mansor at al. 2000 for details). Thus, the government has shown itself to be concerned with the welfare of its workers, resulting in strengthening the logic of employmentincome protection.

In sum, like India and the Philippines, the logic of industrial peace remains institutionalized in the ER system of Malaysia, but is of limited relevance given weak unionism and the fact that collective bargaining covers only a small minority of the urban workforce. The logic of employment-income protection, on the on the other hand, is pursued in Malaysia by a nationalist government, whose legitimacy depends on its image as a champion of Bumiputra rights and co-ordinator of a successful economy, and who is also cognizant of labor shortages. This source of governmental legitimacy is perhaps the only major counterweight to the supremacy of the logic of competition (with its emphasis on attracting and retaining foreign direct investment).

ER Pattern. Government labor policy in Malaysia initially established to prevent and resolve disputes has been transformed mainly in the service of the logic of competition. The issues over which collective bargaining can occur are restricted and the dispute resolution system makes it 
difficult to engage in legal strikes. Additional policies that support the logic of competition include weak enterprise unions (which includes are restrictions on these unions affiliating with industry-level federations in the key export earning electronics industry), and limiting mergers between federations. Meanwhile, the use of guest workers permits numerical flexibility strategies to be followed, and consistent with the logic of competition and employment-income protection, there is a major focus on skills development in a labor shortage economy. Furthermore, the logic of employment-income protection also has led to the development of tripartite frameworks to ameliorate the effects of economic recessions, especially on workers.

Based on our study of 17 Malaysian workplaces, we found an interplay between the logics of competition and employment-income protection, with the former dominating. ${ }^{19}$ The primary focus in almost all workplaces is how to reduce headcount without damaging cordial relations with employees. This is often achieved by retrenchment of mainly foreign workers (6 out of 17 companies recently laid off workers). Other measures include temporary shut-downs, and elimination of sub-contracting and bringing work back in-house. Various forms of wage flexibility usually precede these measures. These include overtime freezes, deferral or nonpayment of bonuses or other contingent forms of pay, postponement of new collective agreements, and more rarely, reductions in base pay (Peetz and Todd 2000).

Work organization varies according to industry, with the protected automobile sector generally characterized by Taylorist systems, although there is some move towards functional flexibility in a minority of companies. This tendency is strongest in the export-oriented electronics industry where functional flexibility is usually achieved with the use of team systems and quality circles. Compensation systems generally include a discretionary element linked to 
performance or contractual bonuses at unionized plants. Except during the financial crisis, high labor turnover of skilled workers has posed a problem for management. Most HR policies designed to deal with this issue focus on improving functional flexibility through employee training and development. For example, in a flagship auto firm, training accounts for $10 \%$ of the wage and salary bill.

Unions have little influence on the ER patterns and practices described above. The only exception to general union weakness is banking, where the industry-wide collective agreement has limits management's discretion and slows the pace of organizational change. The National Bank (Bank Negara) had been persuading bank management to avoid job losses when undertaking workplace restructuring, reflecting official support for a slower adjustment pace in the handling of restructuring.

In sum, changes at workplace level in Malaysia have illustrated the often contradictory dynamics of the logic of competition and the logic of employment-income protection. In general, these logics have been balanced in Malaysia in a way that has not increased industrial conflict, largely because the burden of adjustment has fallen on immigrant workers.

\section{DISCUSSION}

We argue that the differing strength of the logics of action influence the ER patterns of any country, and variation in logic strengths between countries leads to international variation in ER patterns across countries ( propositions 1 and 3). We also argue that the strength of each logic of action depends on five main socio-economic variables (proposition 2). The evidence

\footnotetext{
19. We studied five companies each in electronics and autos, four in banking and three hotels. Of the 17 firms, two were joint ventures between the government and leading Japanese auto companies, eight were American multinationals and the balance, particularly in banking and hotels, a mixture of foreign (Asian) and local firms.
} 
from the four countries, described above and summarized in Table 2, provides support for these three propositions.

\section{INSERT TABLE 2 ABOUT HERE}

As shown in Table 2, the ER systems in India, China, the Philippines and Malaysia exhibit different patterns. Although these patterns are a product of unique historical, economic and political circumstances, their basic contours reflect the interplay of three logics of action whose relative influence varies between countries and over time. We argued that India was characterized by an institutional framework that reflected a preoccupation with industrial peace in an earlier period and a continuing, relatively strong logic of employment-income protection. However, the logic of competition was beginning to assert itself.

India's Protective Regulated pattern contrasts with the Philippines where the logic of competition has overshadowed the other two logics, although the logic of industrial peace continued to provide the rationale for the procedural machinery of the ER system. The Deregulated Competitive pattern in the Philippines bears some similarity with the Chinese ER system, which is also dominated by the logic of competition, but constrained by the logic of

employment-income protection and supported by the logic of industrial peace. China is therefore characterized as a Constrained Competitive pattern, where both the logic of competition and the logic of employment-income protection are growing stronger as the state attempts to maintain social order and retain popular support.

It is unclear whether the constrained competitive pattern now apparent in China will evolve into a more fully developed Protective Competitive pattern of the sort found in Malaysia. In Malaysia's case, the logic of competition has, to some extent, been counterbalanced by the logic of employment-income protection while procedural machinery has been retained to promote industrial peace. 
As Table 2 shows, each of the four country ER patterns reflect the combination of logics and dominance of specific logics. The patterns broadly reflect the dominant logics that we might expect from our earlier discussion of the ER policies and practices associated with each logic. Thus, India's ER policies give workers in the formal economy protection against lay-offs and dismissals within a strong bipartite bargaining framework. State government policies designed to attract investment and workplace practices that emphasize flexibility -- both numerical and functional in different industries, usually in non-union settings -- are underpinned by the logic of competition.

Meanwhile the Chinese government has enacted legislation that protects employees from exploitation, however as noted, implementation of these protections has been uneven and mostly ineffective. This is against the backdrop of policies preventing independent unions and organized conflict. Nevertheless, increasing worker protests against unemployment, and loss of earnings and entitlements, reflects a rising logic of employment-income protection in China to which the government has responded mainly by creating a framework for resolving industrial disputes. In addition, some employers -- particularly Western multinationals and their suppliers - have been aiming to improve productivity and quality, and have therefore begun to emphasize functional flexibility and good wages and working conditions. Most employers, however, seem to be pursuing policies that contain costs and increase numerical flexibility.

The logic of competition has few constraints in the Philippines where the earlier assumptions of decentralized collective bargaining are no longer tenable. Philippine employers are able to avoid unions, and wages and working conditions are, in practice, not regulated by existing legislation.

This is in contrast to Malaysia where the logic of competition can be seen in the government's restrictions on collective bargaining, its guest worker policy, and its human 
resources development strategy. At workplace level in Malaysia , management policies aim at either increasing wage and numerical flexibility or encouraging functional flexibility. The Malaysian government's support for human resource development and protection against unemployment is also associated with the logic of employment-income protection. Meanwhile, unions play a marginal role in a system that is predicated on a tripartite collective bargaining framework.

It is noteworthy that overall the logic of competition is dominant in our cases, and consistent with our argument, we should expect to see gradual reform in ER policies and institutions that were hitherto based on the logic of industrial peace, especially in India, the Philippines and Malaysia. Kuruvilla and Erickson (2001) argue that such a transformation is occurring in many Asian countries generally. The logic of employment-income protection is strongest in Malaysia, and provides a modest counterbalance to the logic of competition, although it appears to be strengthening in China, and if our argument is correct, this logic will become stronger in India as globalization intensifies.

Consistent with proposition 2, a variety of factors affected logic strengths. While a change in the economic development strategy was a critical determinant that strengthened the logic of competition in most countries, the intensity of globalization also exerted strong effects. The logic of competition and the logic of employment-income protection (a reaction to the effects of the logic of competition) were particularly strong in those countries more exposed to globalization such as Malaysia and China.

The cases also support the notion that labor union strength is also an important influence on the logics of action. This is illustrated by differences in the strength of the employmentincome and industrial peace logics in India compared with the other three countries. Government responsiveness to workers also affected the strength of the logic of competition and 
employment-income protection in China and Malaysia, while tight labor markets impacted the ER patterns in Malaysia and the software sector in India.

Our cases also support our fourth proposition that the interplay between different logics influences globalization's effects on employment relations patterns. Where countries have been pursuing an EOI strategy for some time, as in the Philippines and Malaysia, globalization has reinforced already existing tendencies toward increased employer discretion and union weakness based on the logic of competition. This effect is consistent with those who argue that globalization has a negative impact on workers (Greider, 1997). However, our cases also suggest that certain conditions mediate or change this effect. In Malaysia, the logic of employmentincome protection spurred by both tight labor markets and strong government responsiveness to workers’ views, has provided a counterbalance to globalization's negative effects. In India, although major changes in the ER system appear to be on the horizon, the significant point is to note that these changes have not occurred yet, despite almost a decade of economic liberalization. This illustrates the continuing strength of the logic of employment-income protection and the capacity of unions and other political groups to oppose the anticipated excesses of globalization.

The Chinese case in particular, demonstrates the contingent effects of globalization. In China, as noted, the logic of competition has increased in strength ever since China changed it's development strategy in 1978. However, the strong logic of competition, has, over time, also stimulated a gradual strengthening in the logic of employment-income protection. This is evidenced by the government's increasing responsiveness to workers' views bearing in mind that the legitimacy of this socialist, market system is predicated on improvements in workers' and peasants' living standards. A strengthening of the employment-income protection logic is less 
evident in the Philippines case, given its weaker unions, ineffective government ${ }^{20}$, and surplus labor conditions.

The interplay between logics of action is reflected at the workplace. Here, globalization, through the logic of competition, in all four countries, has spurred increasing management assertiveness and control, especially where competition has become a matter of survival. Our research suggests that in industries producing relatively simple manufactured goods, there has been a tendency toward adoption of the low skill-low wage model, characterized by numerical and wage flexibility. Examples of this are in household appliances firms in India, toy, textiles and footwear firms in China, and some auto and electronics firms in the Philippines. With the exception of India, where unions continue to be strong (relatively), these cases highlight the importance of numerical flexibility in non union -workplaces.

In all four countries, in sectors where more complex products have a higher value added element, and product quality and innovation are important, -- software in India, and some electronics in China, the Philippines and Malaysia, and autos in Malaysia,----- a high skill-high wage workplace ER pattern is emerging. Here functional flexibility is the norm. The use of functional flexibility strategies permits the logic of competition to be reinforced by the logic of employment-income protection, even though unions are rare (as in the electronics sector in most countries). In sum, globalization’s impact is not only complex, but contingent, based on the "tug and pull" of different logics.

In terms of the convergence-divergence debate, our fifth proposition suggests that given the interplay between the various logics of action, cross-country convergence in ER patterns in the future is unlikely. The logic of competition, which dominates in three of our four countries,

\footnotetext{
${ }^{20}$ It is unclear whether the Philippines government failed to adequately respond to workers concerns, or whether having responded, it did so ineffectively.
} 
operates mainly through the globalization process in the context of export oriented development strategies. As a result, employers have more discretion, particularly at the workplace, which is likely to lead to cross-firm variation. However, some degree of convergence appears in our cases. This convergence arises from firms responding to intensified competition by adopting similar flexibility strategies based on a flexible, low skill-low wage pattern. This is evident in our four countries, although it is least common in India where unions remain relatively strong.

Divergence outcomes are more prominent in our four countries. Within country divergence in workplace practices results from the variation in the strength of the logic of competition. Contrasting examples include automobiles and banks in India, electronics and hotels in India and Malaysia , greenfield and brownfield sites in India and the Philippines, and SOEs and wholly-owned Western MNC subsidiaries in China. The divergence of ER patterns between countries thus results from within country variation. Such divergence also results from the fact that in different countries, the logic of employment-income protection does not consistently emerge as a counterbalance to the logic of competition. In some countries, governments have acted to provide substantive protections, while in others, such protections are relatively weak. Variations in the extent of institutional frameworks that are associated with the logic of industrial peace also leads to cross-national divergences. The sharpest contrasts are between the regulated Indian and Malaysian ER systems and the de facto relatively unregulated systems of China and the Philippines.

Overall, the tendency towards cross-national divergence is stronger in terms of national level policies and weaker in terms of workplace level practices. The interplay between different logics of action suggests the forces promoting divergence are stronger than those favoring convergence. 


\section{CONCLUSION}

In this paper we develop a framework that focuses on the underlying logics that shape decisions about employment relations policy and workplace practices in different countries. We argue that employment relations patterns (policies and practices) in any country at any given time reflect a combination of three different logics of action, namely, the logic of competition, the logic of industrial peace, and the logic of employment-income protection. Case studies of 54 firms from 13 industries, and an analysis of national level policy making in India, China, Malaysia and the Philippines, demonstrate that the relative strength of these logics vary between countries and wax and wane over time within countries in response to several factors. These factors include a nation's economic development strategy, the intensity of globalization, government responsiveness to workers' expectations, labor market features, and union strength. The cases also reveal that different combinations of logic strengths lead to differences in ER patterns. Four different patterns were identified: Regulated Protective (India), Constrained Competitive (China), Deregulated Competitive (Philippines) and Protective Competitive (Malaysia).

The logics of action framework enabled us to contribute to two related debates: one regarding the impact of globalization on ER systems, and the other relating to whether national ER systems are converging or diverging. Given the variation in the strengths of different logics of action, and the interplay between logics, we find that globalization,----- expressed through the logic of competition----- has complex and contingent effects on employment practices. Of particularly importance is the point that the logic of competition causes some realignment of ER policies, institutions, and practices consistent with this logic. However, in response to the

effects of the logic of competition, the logics of of employment-income protection and industrial peace often tend to strengthen. We also found that the realignment that occurs with the logic of 
competition is felt more immediately in the workplace rather than at the national policy level. In sum, our contribution provides both evidence for, and an interpretation of, the impact of globalization on employment relations in developing countries.

With regard to the employment system convergence-divergence debate, we agree with those researchers who have argued in favor of divergence. We would go even further however, by arguing that cross-national convergence is highly unlikely, given the constantly changing relationship between different logics of action. At the same time, our cases illustrate weak convergence at the workplace level, fostered mainly by globalization, underpinned by the logic of competition. Yet, given the interplay between the logics of action, there is no warrant for assuming this process will continue in the longer term.

There are several ways in which future research might build on the analysis developed in this article. Theoretically, it may be possible to construct models based on various likely combinations of logics of action that may make ER patterns easier to predict and examine empirically. There is also a case for reformulating ER patterns as configurations of specific variables that are likely to co-exist together at various levels (national, industry and workplace). The likely determinants of the combinations of logics of action that give rise to these configurations need to be explored across more cases and over time for it is quite likely that the restricted range of our research has not uncovered all the factors influencing logic strength. In addition, more elaborate models can be developed, linking some characteristics of business systems -- the structure and dynamics of employer groups and emerging national training arrangements within ER systems.

On the empirical and methodological side, it would be useful to develop more precise ways of measuring logics, rather than inferring their presence, as we do, from a combination of interview data, documentary sources, and outcomes. Further, more purposeful sampling of firms 
and industries would be useful to extend the kind of inductive analysis we have conducted. Where access to workplaces is likely to be time consuming and difficult, appropriate samples in other developing countries may need to be drawn with government and employer organization support.

In sum, we have demonstrated that the logics of action framework is a useful and simple interpretative schema for understanding changes in the nature and direction of employment relations systems. In drawing attention to the importance of the interaction between the logics of competition, employment-income protection and industrial peace, our research also suggests possible future scenarios, and highlights the need for policymakers to develop strategies that seek to balance the three logics of action according to widely debated and explicit social values. 


\section{REFERENCES}

Asian Development Bank (ADB). 2001. "Malaysia Update". www.adb.org.

Barley, Stephen R., and Tolbert, Pamela S. 1997. "Institutionalization and Structuration: Studying the Links between Action and Institution.” In Organization Studies, Vol. 18, pp. 93117.

Barranco-Fernando, Nenita. 1996. "Globalization and its Impact on the Philippine Labor Market." In Philippine Journal of Labor and Industrial Relations, Vol. 16, Nos. 1 \& 2, pp. 6998.

Bhattacherjee, Debashish. (2001). Paper Prepared for the ILO Conference on Trade Unions and Globalization to be held at Geneva, 19-21 April 2001.

Chiang, T.B. 1988. "The Administration and Enforcement of Collective Agreements in Singapore.” In The Adminstration and Enforcement of Collective Agreements-A Survey of Collective Agreements in ASEAN. Bangkok: International Labor Organization pp. 239-46.

Child, John. 1994. “Management in China during the Age of Reform”. Cambridge: Cambridge University.

Chiu, Stephen and Stephen Frenkel. 2000. Globalization and Employment Relations in China. ILO: Bangkok.

Das, Subesh. 2000. “A Note on Trade Union Density in India”. Working Paper, Department of Collective Bargaining, Cornell University.

De la Garza, Enrique M. "Converging Divergences or Converging through Four Patterns". In Industrial \& Labor Relations Review, No. 54, 3, pp. 694-697.

DeSouza, Valerian. “Colonialism and Industrial Relations in India.” In Kuruvilla, Sarosh and Bryan Mundell, 1999 Ed., "Colonialism and the Institutionalization of Industrial Relations in Developing Nations.” In Organizational Behavior and Industrial Relations. No. 25 (Series Editor: S. Bacharach). Stamford, CT: JAI Press.

Ding, Daniel, Dail Fields, Syed Akhtar. 1997. “An Empirical Study of Human Resource Management Policies and Practices in Foreign-invested Enterprises in China: The Case of Shenzen Special Economic Zone.” In International Journal of Human Resource Management, Vol. 8, No. 5, pp. 595-610.

Ding D.Z. and Malcolm Warner. 1999. "Re-inventing China's Industrial Relations at Enterpriselevel: An Empirical Field-study in Four Major Cities.” In Industrial Relations Journal, Vol. 30, No. 3, pp. 243-260. 
Dore, R. 1974. British Factory-Japanese Factory: The Origins of National Diversity in Industrial Relations. Berkeley: University of California Press.

Dore, R. 1989 “Where are we Now: Musings of an Evolutionist”. In Work, Employment \& Society, Vol 3, No. 4, pp.425-46.

Esguerra, J, Balisacan, A, and Confesor, N. (2001). The Philippines: Labor Market Trends and Government Interventions Following the East Asian Financial Crisis. In Betcherman, $G$ and Islam, R. (Eds), East Asian Labor Markets and the Economic Crisis: Impacts, responses and Lessons. The World Bank.

Freund, Elizabeth, M. 1998. “Downsizing China’s State Industrial Enterprises.” In Greg O’Leary, ed., Adjusting to Capitalism: Chinese Workers and the State. Armonk, NY: M.E. Sharpe.

Frenkel, Stephen, 2001 "Globalization, Athletic Footwear Commodity Chains and Employment Relations in Southern China.” In Organization Studies, Vol 22, No. 4, pp. not available yet.

Frenkel, Stephen and David Peetz. 1998. “Globalization and Industrial Relation in East Asia: A Three-Country Comparison.” In Industrial Relations. Vol. 37, No. 3, pp.282-310.

Goodall, Keith and Malcolm Warner. 1997. "Human Resources in Sino-foreign Joint Ventures: Selected Case Studies in Shanghai Compared with Beijing”. In International Journal of Human Resource Management. Vol. 8, No. 5, pp. 569-593.

Greider, W. 1997. One World, Ready or Not: The Manic Logic of Global Capitalism. New York: Simon \& Schuster.

The Guardian Weekly. 2000. “Labor Unrest in China Reflects Increasing Disenchantment,” May 4-10, p. 37.

Hiers, Wesley and Sarosh Kuruvilla. 2000. Globalization and Industrial Relations in India. ILO: Bangkok.

Hiers, Wesley and Arudsothy, Ponniah. 1999. "From Ostensible Voluntarism to Interventionism in Malaysian Industrial Relations: The colonial experience as an important Variable.” In Kuruvilla, Sarosh and Bryan Mundell, Eds., 1999, "Colonialism and the Institutionalization of Industrial Relations in Developing Nations." Organizational Behavior and Industrial Relations, Vol. 25, (Series Editor: S. Bacharach). Stamford, CT: JAI Press.

ILO 2000. “Globalization and Employment Relations in Asia.” Forthcoming, ILO: Bangkok. International Monetary Fund (IMF). 1999. World Economic Indicators.

Katz, Harry, C. and Owen Darbishire. 2000. Converging Divergences: Worldwide Changes in Employment Systems. Ithaca: Cornell University Press. 
Kerr, C, Dunlop, J., Harbison, F. and C. Myers. 1960. Industrialism and Industrial Man. Cambridge: Harvard University Press.

Klein, Naomi. 2001. No Logo. London: Flamingo.

Kuruvilla, Sarosh. 1996. “The Relationship Between Economic Development Strategies and Industrial Relations: India, Malaysia, Singapore and the Philippines.” In Industrial and Labor Relations Review. Vol 49, No. 4, pp. 635-657.

Kuruvilla, Sarosh, Christopher Erickson, Mark Anner, Rene Ofreneo, Maragtas Amante, and Ina Ortiz. 2000. Globalization and Industrial Relations in the Philippines.” ILO: Bangkok, Forthcoming.

Kuruvilla Sarosh and Rodney Chua. 2000. "How Do Nations Develop Skills? Lessons from the Skill Development Experiences of Singapore" Global Business Review, Vol 1, No. 1. Jan-June 2000, pp. 11-49.

Kuruvilla, Sarosh and Bryan Mundell. 1999. "Colonialism and the Institutionalization of Industrial Relations in Developing Nations.” In Organizational Behavior and Industrial Relations, Vol. 25, (Series Editor: S. Bacharach), Stamford, CT: JAI Press, pp. 1-19.

Kuruvilla, Sarosh and Christopher Erickson. 2000. “Change and Transformation in Asian Industrial Relation”. In Press. Industrial Relations

Lamberte, M.C.C., Guerrero, and Orbeta, A. 1999. Results of the Survey of Philippine Industry and the Financial Crisis. Unpublished paper, cited in Esguerra, Balisacan and Confesor (2001).

Lee, Ching Kwan. 1999. “From Organized Dependence to Disorganized Despotism: Changing Labour Regimes in Chinese Factories”. In The China Quarterly, No. 57, pp. 44-71.

Leisink. Peter. 1999. “Introduction”. In Peter Leisink, ed., Globalization and Labour Relations, Edward Elgar: Cheltenham UK.

Lincoln, James R. and Kalleberg, Arne L. 1990. Culture, Control, and Commitment. Cambridge: Cambridge University Press.

Locke, Richard M. 1992 "The Demise of the National Union in Italy: Lessons for Comparative Industrial Relations Theory”. In Industrial \& Labor Relations Review, Vol. 45, No. 2, pp. 229-249.

Ofreneo, Rene. 2000. “Globalization and the Asian Economic Crisis: An Assessment of the Social Accord Initiatives in the Philippines”. Paper Presented at the World Congress of the International Industrial Relations Association, Tokyo, May-June 2000.

Ofreneo, R. and Ortiz, I., 1998. "Globalization and Employment Relations in the Philippines.” School of Labor and Industrial Relations, University of the Philippines. Working paper 
Peetz and Todd. 2000. “Globalization and Employment Relations in Malaysia." ILO: Bangkok.

Sen, Amartya. 2001. "Global Doubts as Global Solutions," Alfred Deakin Lectures, Radio National, Melbourne Australia, downloaded from www.abc.net.au/rn/deakin/stories/s296978.htm, speech delivered on May 15, 2001.

Seung, Wook Baek. 2000. “The Changing Trade Unions in China”. In Journal of Contemporary Asia, Vol. 30, No. 1, pp. 46-66.

Schlevogt, Kai Alexander. 2000. “The Distinctive Structure of Chinese Private Enterprises: A Comparison between the State and Private Sector”. In Asia Pacific Business Review, Vol. 6, Forthcoming.

Sharma, Basu. 1985. “Aspects of Industrial Relations in ASEAN”. In Singapore: Institute for Asian Studies.

Sheehan, J, J. Morris, and J. Hassard. 2000. "Redundancies in Chinese State Enterprises: A Research Report”. In Industrial Relations, Vol. 39, No. 3, pp. 486-501.

Singh, Ajit. and Zammit, Ann. 2000. The Global Labour Standards Controversy: Critical Issues for Developing Countries.” Geneva: South Centre.

Villegas. E. 1988. “The Political Economy of Philippine Labor Laws.” In Quezon City, Philippines: Foundation for Nationalist Studies Inc., 1988. pp. 38-51

Venkataratnam, C.S. 1993. "Impact of New Economic Policies on the Role of Trade Unions.” In Indian Journal of Industrial Relations, Vol 29, No. 1 (July), pp. 56--77.

Venkatratnam, C.S. and Naidu, D.P.A. (1999) Industrial Relations and Collective Bargaining in South Asia. The Trade Union Perspective. ILO: ACTRAV, SAAT, Geneva and New Delhi

Whitley, Richard 2000. Divergent Capitalisms: The Social Structuring and Change of Business Systems. Oxford: Oxford University Press.

Zhao, Minghua and Theo Nichols. 1996. "Management Control of Labor in State-owned Enterprises: Cases from the Textile Industry.” China Journal, No.36, July, pp. 1-21. 
Table 2: Logic of Action Strength Combinations and Employment relations patterns in India, China, the Philippines and Malaysia

\begin{tabular}{|l|l|l|}
\hline Country & Logic of Action Strength & Employment Relations Pattern \\
\hline India & $\begin{array}{l}\text { Industrial peace: strong } \\
\text { Employment -income } \\
\text { protection : weak, declining } \\
\text { Competition: weak, } \\
\text { increasing. }\end{array}$ & $\begin{array}{l}\text { Protective Regulated } \\
\text { Policy: Strong protective legislation regarding union formation and bipartite } \\
\text { collective bargaining, interventionist dispute settlement machinery, strong } \\
\text { legislation with respect to potential causes of industrial disputes (defacto no } \\
\text { retrenchments, laws protecting casual workers and restricting subcontracting). } \\
\text { Changes in ER Policy at the State level to more pro-business orientation; debates } \\
\text { at central level on labor law reform demanded by employers. } \\
\text { Practice: General focus on numerical flexibility via voluntary retirement, more } \\
\text { aggressive management practices (union avoidance and greenfield strategies), } \\
\text { gradual introduction of functional flexibility in some sectors, and greater change } \\
\text { in industries more exposed to globalization. In general, more variation in ER in } \\
\text { the economy. }\end{array}$ \\
\hline
\end{tabular}




\begin{tabular}{|c|c|c|}
\hline China & $\begin{array}{l}\text { Industrial peace: weak, } \\
\text { increasing } \\
\text { Employment-income } \\
\text { protection: weak, increasing } \\
\text { Competition: strong }\end{array}$ & $\begin{array}{l}\text { Constrained Competitive } \\
\text { Policy: Labor law permits short-term contracts, layoffs, performance based pay } \\
\text { and much more geographical labor mobility than in the past. The Labor law also } \\
\text { specifies minimum standards for wages and working conditions, and encourages } \\
\text { unions and bargaining. Dispute settling machinery is also available. } \\
\text { Practice: ER practices in SOEs emphasize cost reduction, numerical flexibility, } \\
\text { labor intensive employment, and Taylorist work practices. Underemployment, } \\
\text { layoffs and consequent worker protests are problems that the government is } \\
\text { taking more seriously. .Some limited efforts at functional flexibility in SOEs but } \\
\text { increasing rapidly in Western foreign-invested companies. Higher wages and } \\
\text { better conditions in these firms contrast with SOEs. ER variation linked to sector } \\
\text { (state vs foreign-invested) and ownership (Hong Kong/Taiwan vs } \\
\text { European/American firms). }\end{array}$ \\
\hline $\begin{array}{l}\text { Philippine } \\
\text { s }\end{array}$ & $\begin{array}{l}\text { Industrial peace: weak } \\
\text { Employment-income } \\
\text { protection: n weak } \\
\text { Competition: strong }\end{array}$ & $\begin{array}{l}\text { Deregulated Competitive } \\
\text { Policy: Pluralist collective bargaining legislation exists but increasingly } \\
\text { irrelevant given low collective bargaining coverage, union fragmentation, and } \\
\text { very limited enforcement of labor law. Regional and Export processing zones } \\
\text { emphasize non-union policies. Limited efforts to revitalize tripartism and skills } \\
\text { development. } \\
\text { Practice: Mostly a focus on numerical and wage flexibility via layoffs, } \\
\text { casualization and labor-only contracting. Rampant anti-union practices. Some, } \\
\text { mainly foreign-owned semi-conductor firms focus on functional flexibility. }\end{array}$ \\
\hline
\end{tabular}




\begin{tabular}{|c|c|c|}
\hline & & $\begin{array}{l}\text { Gradual introduction of competitive practices in recently privatized and } \\
\text { deregulated sectors however ER patterns have not yet consolidated. }\end{array}$ \\
\hline Malaysia & $\begin{array}{l}\text { Industrial peace: weak } \\
\text { Employment-income } \\
\text { protection: increasing to } \\
\text { fairly strong } \\
\text { Competition : strong }\end{array}$ & $\begin{array}{l}\text { Protective Competitive } \\
\text { Policy: legislation restricts union formation and mergers between union } \\
\text { federations; support for enterprise unions and restrictions on range of bargaining } \\
\text { issues. Administrative rules circumscribe the right to strike. Laws and } \\
\text { institutions promote skill formation, guest worker policy, revitalization of } \\
\text { tripartite arrangements during Asian financial crisis, strong collective bargaining } \\
\text { in banking, and legal introduction of severance pay and policy on industrial } \\
\text { harmony. } \\
\text { Practice: Cost reduction via numerical and wage flexibility with burden mainly } \\
\text { falling on foreign workers. Work organization mainly Taylorist with exceptions } \\
\text { in auto and electronics industries where functional flexibility is more common. } \\
\text { Weak collective bargaining, except in the banking sector were changes is slow. } \\
\text { Domestic workers are protected by legislation against lay-offs and inferior } \\
\text { working conditions. Legislation is enforced. Variation in ER patterns likely to } \\
\text { increase with reduced impact of the financial crisis and government support for }\end{array}$ \\
\hline
\end{tabular}




\begin{tabular}{|l|l|l|}
\hline & & functional flexibility. \\
\hline
\end{tabular}

